\title{
FÁCIES SEDIMENTARES E MODELO DE SEDIMENTAÇÃO DO GRUPO PARAGUAÇU NA REGIÃO DE RIO DE CONTAS, BORDA OCIDENTAL DA CHAPADA DIAMANTINA, BAHIA
}

\author{
GERALDO DA SILVA VILAS BOAS*, ANTÔNIO MARCOS SANTOS PEREIRA*, FLÁvio JOSÉ SAMPAIO**
}

\begin{abstract}
SEDIMENTARIES FACIES AND SEDIMENTATION MODEL FOR THE PARAGUACUU GROUP IN RIO DE CONTAS REGION, WESTERN BORDER OF CHAPADA DIAMANTINA, BAHIA. The Middle Proterozoic metasediments of the Paraguacu Group, outcropping in the Rio de Contas region, on the western border of the Chapada Diamantina (Bahia), consist of three terrigenous sedimentary facies displaying characteristic features of eolian-, coastal-, and shelf-type depositional environments. The facies 1 , which occupies the basal portion of the sequence, is made up of quartzites and laminated metasandstones interpreted as transgressive in nature, and deposited over as extensive shallow marine platform showing storm effects. The intermediate facies 2 is composed of quartzites with large scale high-angle cross-bedding defined as eolian is origin, accumulated on vast coastal dune fields. Facies 3 , which constitutes the top of the group, starts with transgressive, fine, and laminated metasandstones (sub-facies $3 \mathrm{~A}$ ) deposited in a shoreface environment, under moderate energy conditions. This is overlain by muddy deposits (sub-facies 3B), also transgressive in nature and accumulated in a shelf environment submitted to hydraulic regimes of alternating calm and stormy periods. The uppermost facies of the Paraguaçu Group (sub-facies 3C) consists of metasiltstones and metasandstones deposited in a shoreface zone, prograding over a muddy shelf.
\end{abstract}

\begin{abstract}
RESUMO Os metassedimentos do Proteroź́ico Médio do Grupo Paraguaçu aflorantes na região de Rio de Contas, na borda oeste da Chapada Diamantina (Bahia), consistem de trés fácies sedimentares terrígenas. As unidades mostram feiçóes caracteristicas de deposição élica costeira e de ambientes deposicionais tipo plataforma. A fácies 1, que ocupa a porção basal da seqüência, é formada por quartzitos e metarenitos laminados, interpretados como de natureza transgressiva, e depositados como sedimentos de uma extensa plataforma marinha rasa. Apresentam feiçóes originadas pela ação de tempestades. A fácies 2, intermediária, $\epsilon$ composta de quartzitos com estratificaçóes cruzadas de grande porte e alto ângulo definidos como de origem élica, acumulados num vasto campo de dunas costeiras. A fácies 3 , que constitui o topo da seqüência, começa com metarenitos transgressivos finos e laminados (sub-fácies 3A) depositados em ambiente de antepraia, sob condiçóes de energia moderada. Ela 6 sobreposta por sedimentos lamosos (sub-fácies 3B), também de natureza transgressiva e acumulados em ambiente de plataforma, submetido a um regime hidráulico de alternância de períodos de calma e de tempestades. A fácies mais superior do grupo Paraguaçu (subfácies 3C) consiste de metassiltitos e metarenitos depositados em zona de antepraia, progradante sobre uma plataforma lamosa.
\end{abstract}

INTRODUÇĀo As seqüências terrígenas paraplataformaìs acumuladas em sítios de deposiçăo gerados sobre o Cráton do São Francisco, durante o Mesoproterozóico (Inda \& Barbosa 1978), são o registro de importantes eventos sedimentogênicos ali ocorridos durante este segmento do tempo geologico. Grande parte dessas seqüências. E representada pelos metassedimentos do Grupo Paraguaçu que afloram na regiáo da Chapada Diamantina Ocidental, no Estado da Bahia. As rochas deste grupo têm sido objeto de inúmeros trabalhos e de estudos geológicos que enfocam, sobretudo, aspectos estratigráficos, petrográficos e tectônicos, sendo muito pouco conhecidas as características ambientais de deposiçáo dessas rochas. Considerando-se a natureza essencialmente sedimentar do Grupo Paraguaçu, essa carência de dados sobre seu ambiente de deposição representa uma séria lacuna para a interpretaçấo da história geológica regional.

Assim, visando contribuir para um melhor conhecimento das condiçōes de deposiçã̃o do Grupo Paraguaçu e, conseqüentemente, da história geologica dâ regiāo da Chapada Diamantina, o presente trabalho tem como objetivo o estudo sedimentológico das rochas desse grupo aflorantes na região de Rio de Contas, Bahia (Fig. 1), pela identificação e caracterização das fácies sedimentares presentes e, conseqüentemente, a interpretação dos processos e ambientes de sedimentaçáo. Isso é possível porque essas rochas ainda preservam grande parte das feições primárias, como as estruturas sedimentares.
GEOLOGIA DA ÁREA Na área estudada ocorrem rochas arqueanas do Pré-Espinhaço pertencentes ao complexo Metamórfico-Migmatítico, rochas do Mesoproteroźico dos grupos Rio dos Remédios e Paraguaçu, do Supergrupo Espinhaço (Barreto et al. 1975), além de intrusivas básicas e extensas coberturas terrígenas cenoz6icas (Fig. 1).

O Complexo Metamórfico-Migmatítico é representado por xistos de coloração castanha a cinza, com textura porfiroblástica, lepidoblástica e milonítica, constituídos principalmente de sericita, quartzo e quantidades subordinadas de magnetita. Esses xistos exibem duas foliaçōes com atitudes de N130 83 NE e N140 $75 \mathrm{SW}$, respectivamente, sendo a primeira mais proeminente. Segundo Barreto et al. (op. cit.), essas rochas são resultantes do microquebramento de rochas gnáissico-migmatíticas preexistentes, por ação de metamorfismo dinâmico que teria afetado a regiăo durante o Ciclo Orogenético Transamazônico. Moutinho da Costa \& Inda (1982) atribuem o quebramento e a transformaçáo das rochas do Complexo Metamórfico-Migmatítico em xisto-verde a ação de movimentos verticais durante as diversas fases de deformação ligados à evoluçẫo de uma estrutura do tipo aulacógeno.

O Grupo Rio dos Remédios é constitúdo por uma seqüência terrígena basal representada por quartzitos finos, maturos, de cor cinza a rosa, com níveis metaconglomeráticos subordinados e uma seqüência de topo formada por rochas xistosas de origem vulcânica, compreendendo tipos petrográficos ácidos e intermediários. Essas rochas estäo

* Programa de Pesquisa e Pós-Graduação em Geoffsica e Instituto de Geociências da UFBA. Rua Caetano Moura, 123, Federação, CEP 40210, Salvador, BA, Brasil 


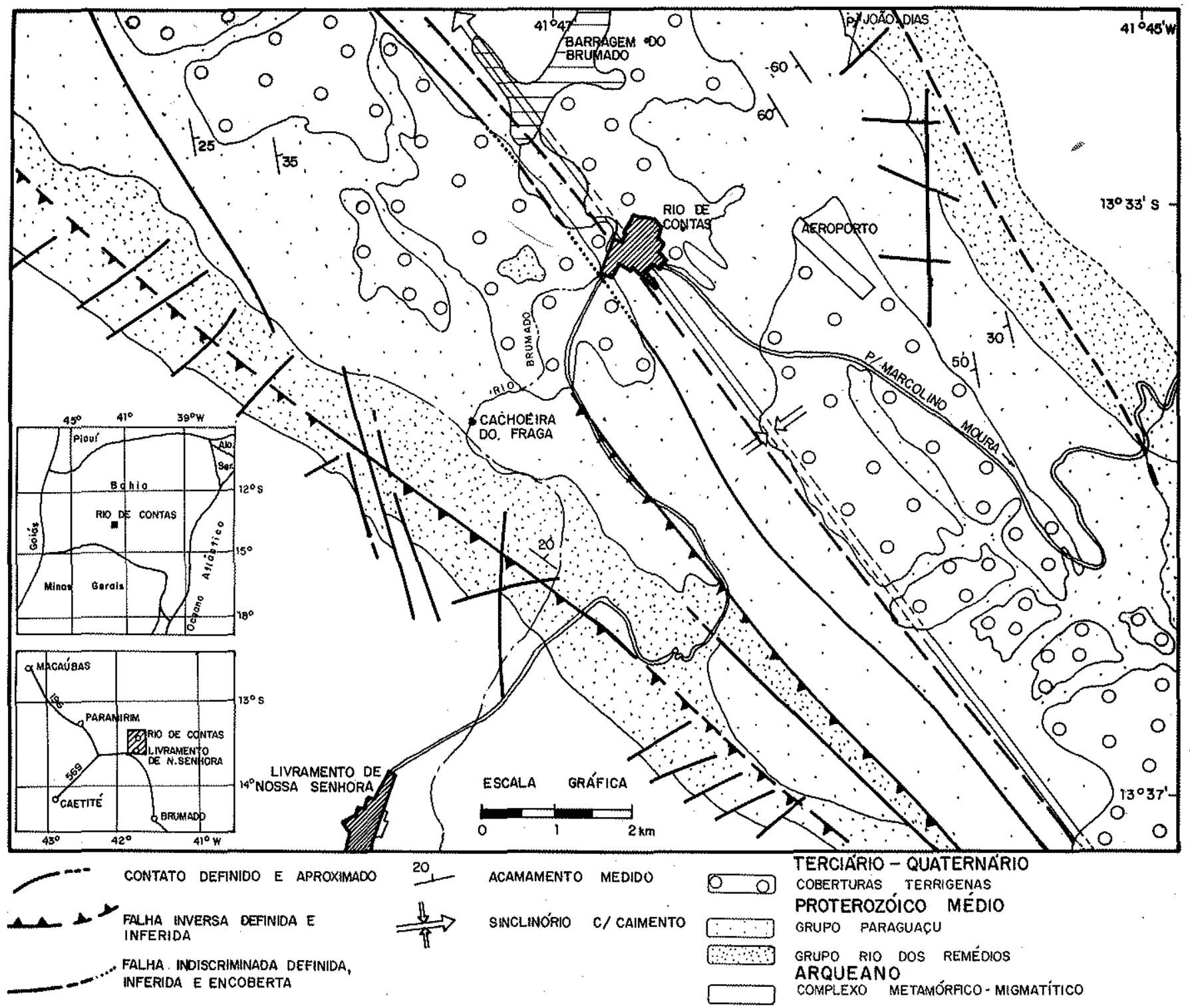

Figura 1-Mapa geologico simplificado da área

sobrepostas em grande parte em discordância litologica às rochas do Complexo Metamórfico-Migmatítico. Localmente, o contato entre essas duas unidades é feito por falhamento inverso, tal como ocorre no leito do Rio Brumado, nas proximidades de Livramento de Nossa Senhora (Fig.1).

O Grupo Paraguaçu é representado por uma espessa seqüência terrígena constituída de quartzitos com intercalaçōes de metaconglomerados em posição "basal, quartzitos em posição intermediária e metarenitos e metapelitos no topo. Essa seqüência repousa em discordância erosiva sobre as rochas do Grupo Rio dos Remédios. As características litológicas, a seqüência vertical e o significado ambiental dos metassedimentos do Grupo Paraguaçu são discutidos mais adiante.

As seqüências representativas dos grupos Rio dos Remédios e Paraguaçu ocorrem na área constituindo uma estrutura do tipo sinclinório (Sinclinorio de Rio de Contas), com eixo na direção NW-SE, mergulhando suavemente para NW (Fig. 1). As medidas de acamamento revelam variaçöes nas atitudes dessas rochas em ambos os flancos do sinclinório, muito embora a direção geral e a tendência dos mergulhos sejam mantidas, ou seja: N120 10 a 45 NE e N110 35 a
$60 \mathrm{SW}$, respectivamente, nos flancos SW e NE. Essas rochas exibem uma conspícua foliação de plano axial com direçāo média de N130 e mergulho variável de $45^{\circ}$ a subvertical. Essa foliaçäo tem vergências para NE e SW, conforme estejam nos flancos SW e NE, respectivamente. As unidades dos Grupos Rio dos Remédios e Paraguaça se encontram intensamente falhadas na área estudada, estando presentes falhas transversais, longitudinais e inversas. Alem das rochas intrusivas básicas, os veios de quartzo aparecem também, muitas vezes, preenchendo as fraturas e falhas que cortam os metassedimentos dos dois grupos.

FÁCIES SEDIMENTARES DO GRUPO PARAGUAÇU A medição, a descriçăo e a análise detalhadas de várias seçóes estratigráficas permitiram a individualização das diversas fácies sedimentares que constituem o Grupo Paraguaçu na regiăo estudada. A caracterização dessas fácies foi feita tomando por base os tipos e as associações de estruturas sedimentares, bem como a natureza litológica, de modo que cada uma das fácies distinguidas pudesse ser associada a determinadas condições de sedimentação que refletem um tipo particular de processo ou ambiente. Foram identificadas três 
fácies distintas constituindo o Grupo Paraguaçu: 1. fácies 1 quartzitos e metarenitos laminados; 2. fácies 2 - quartzitos com estratificações cruzadas de grande porte e 3 . fácies $3-$ metarenitos finos laminados, metassiltitos e ardósias. A figura 2 mostra a distribuição dessas fácies na área estudada enquanto na figura 3 são vistas esquematicamente as características e as relaçöes verticais entre as mesmas bem como as respectivas interpretaçőes ambientais.

Fácies 1 - Quartzitos e metarenitos laminados Esta fácies constitui a parte basal do Grupo Paraguaçu na área estudada. Repousa em discordância erosiva sobre as rochas do Complexo Rio dos Remédios e atinge uma espessura média de cerca de $200 \mathrm{~m}$. Affora constituindo elevadas escarpas esculpidas nos flancos do sinclinório de Rio de Contas e está representada por duas faixas com larguras entre 500 e 1.500 m orientadas na direção NW-SE (Fig. 2). É caracterizada por quartzitos e metarenitos de cor rósea a cor de creme, granulação fina a muito grossa, com intercalaçöes de níveis granulosos e cascalhosos. Esses quartzitos såo na maioria das vezes constituídos de mais de $95 \%$ de quartzo, com quantidades subordinadas de fragmentos de rocha, sericita, minerais opacos e, mais raramente, turmalina. Apresentam uma textura granoblástica, ineqüigranular $\mathrm{e}$, menos freqüentemente, cataclástica. $O$ quartzo ocorre principalmente em grãos xenoblásticos de 0,2 a $1 \mathrm{~mm}$, com extinção normal e, menos comumente, extinção ondulante. Mostra contatos reentrantes e apresenta algumas vezes crescimento secundário. Os fragmentos de rocha aparecem em geral em porcentagens inferiores a $5 \%$, são em grande parte de origem vulcânica e constituídos de quartzo microcristalino ou por um agregado de quartzo microcristalino e sericita. Mais raramente, estão presentes fragmentos de quartzito de granulação muito fina. A sericita se apresenta em plaquetas finas e incolores, orientadas. Os minerais opacos ocorrem sob a forma de grãos finos xenoblásticos dispersos na rocha. A turmalina se apresenta em cristais prismáticos de cor esverdeada, formando concentraçöes localizadas. Nas partes mais basais das seqüências representativas da fácies, em uma faixa de ate $20 \mathrm{~m}$, a porcentagem de fragmentos de rocha de origem vulcânica pode atingir algumas vezes valores de ate $25 \%$ e, excepcionalmente, $35 \%$, com os quartzitos passando, desta forma, a metarenitos sub-líticos e líticos. As estruturas sedimentares presentes nesses quartzitos e metarenitos são principalmente as laminações plano-paralelas e as laminações cruzadas de baixo ângulo. Freqüentemente são tambem encontradas estratificaçōes cruzadas tabulares e, mais raramente, estratificações cruzadas acanaladas e cuneiformes,

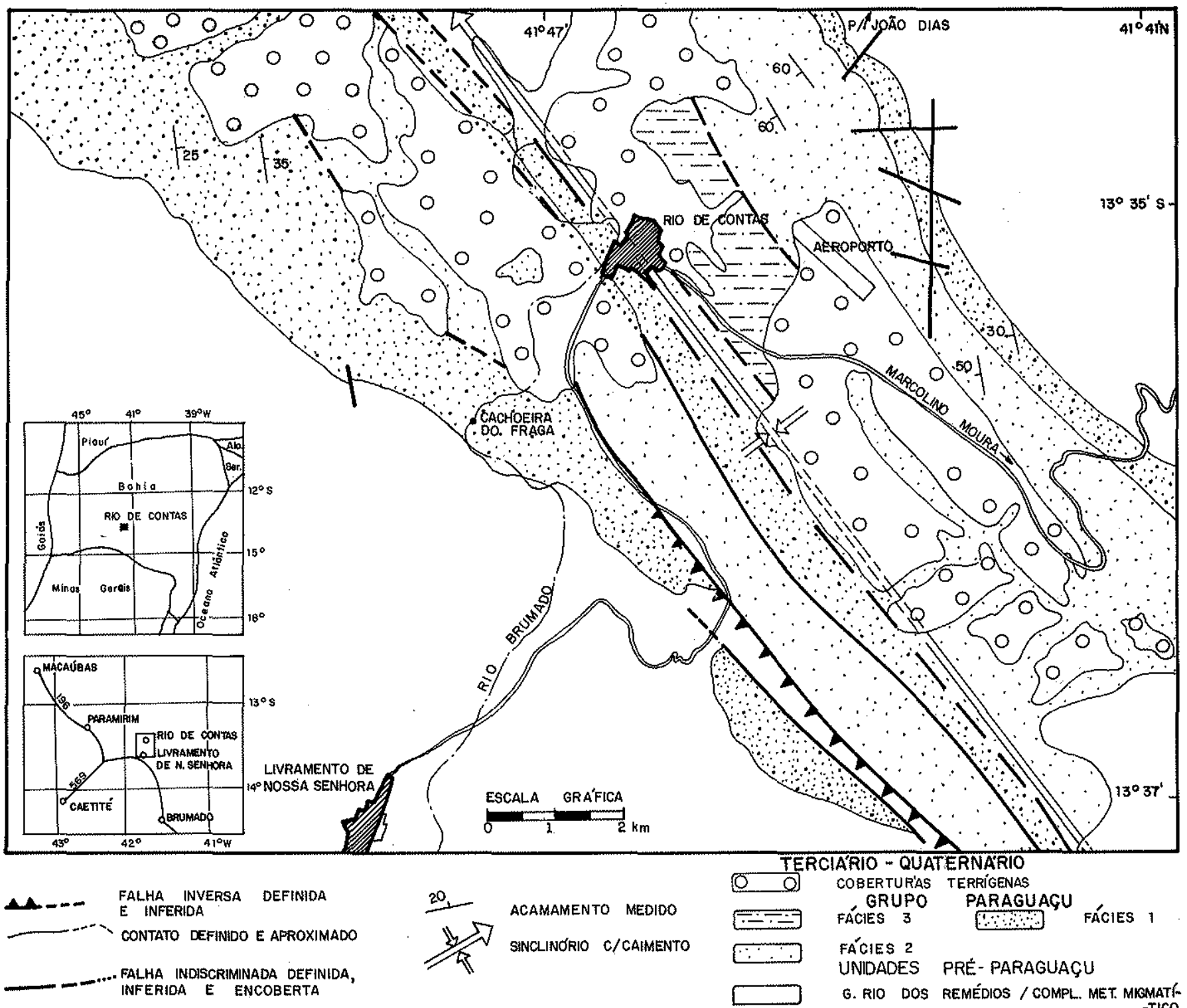

Figura 2-Mapa das fácies sedimentares do Grupo Paraguaçu na área estudada 


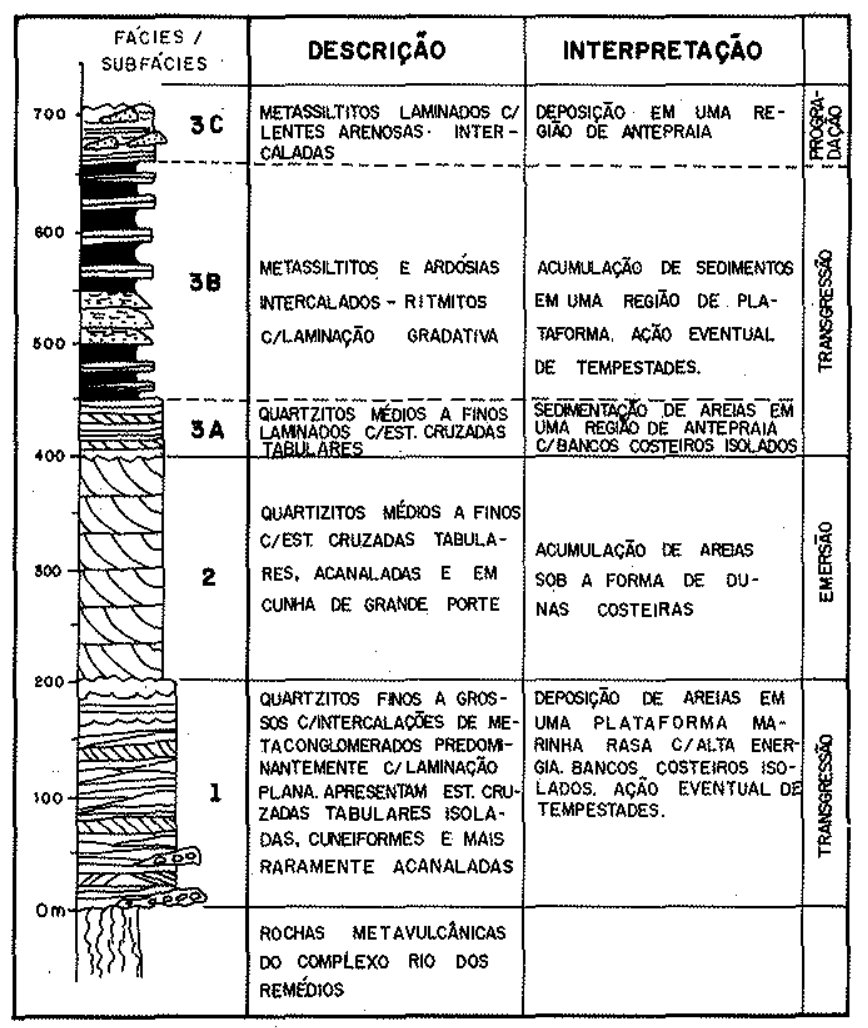

Figura 3 - Sucessão vertical das fácies do Grupo Paraguaçu na área estudada

bem como estratificaçōes gradativas. Estão também presentes níveis de metaconglomerados em posição basal e/ou interestratificados com os quartzitos nas partes mais basais da fácies.

As laminações plano-paralelas são as feições mais proeminentes da fácies 1 e ocorrem em mais de $70 \%$ da espessura total đa mesma. As lâminas têm em geral espessuras inferiores a $2 \mathrm{~mm}$, grande extensăo lateral e são marcadas por pequenas variaçóes granulométricas. Algumas vezes são observadas lâminas com estrutura gradativa normal. Em geral, os contatos entre as lâminas são bruscos e representados por superfícies de natureza erosiva planas ou suavemente onduladas (Foto 1A). Os níveis de metarenito e quartzitos laminados formam bancos de espessuras decimétricas a métricas com contato basal e de topo bruscos ou limitados por superfícies de descontinuidade planas dispostas paralelamente à laminação ou suavemente inclinadas em relaçẫo às mesmas. No topo desses bancos, freqüentemente, aparecem marcas onduladas simétricas (Foto 1B), assimétricas $\mathrm{e}$ de interferência. São também freqüentes ao longo de toda a fácies níveis com laminação ondulada paralela associados aos horizontes com laminação plana. Muitas vezes, esses níveis são truncados no topo por superfícies de erosão irregulares ou onduladas.

As laminações cruzadas de baixo ângulo apresentam características semelhantes às laminações plano-paralelas com as quais se associam intimamente ao longo da fácies 1. Elas formam seqüências com lâminas frontais de grande extensão lateral e ângulo de mergulhos suaves; inferiores a $10^{\circ}$.

As estratificações cruzadas tabulares aparecem em seqüências isoladas com espessuras de 0,10 a $1,20 \mathrm{~m}$, intercaladas nos níveis com laminação plana. As camadas frontais são em geral planas e têm contatos angulares com as superfícies basais das seqüencias. $O$ ângulo de mergulho dessas camadas em relação à superfície de deposição original pode atingir até $30^{\circ}$. Menos comumente, são ainda encontradas estratificaçöes cruzadas nas quais se associam sequiências com geometria em cunha e cujas camadas frontais apresentam direçôes variáveis e ângulos đe mergulhos baixos (Foto $2 \mathrm{~A}$ ). As estratificaçōes cruzadas acanaladas ocorrem em unidades com espessuras de 10 a $30 \mathrm{~cm}$ associadas em co-sequiências intercaladas nos níveis laminados (Foto 2B).

As estratificações građativas normais aparecem constituindo horizontes lenticulares centimétricos e exibindo contatos basais bruscos com os horizontes subjacentes (Foto 3). Em geral, a base de cada nível gradativo é constituída de areia grossa - muito grossa e/ou grânulos passando a areia fina -- muito fina no topo.

Os niveis de metaconglomerados têm comumente espessuras de até $2 \mathrm{~m}$, sendo os da posição mais basal geralmente os mais espessos. Os contatos basais com os metarenitos e quartzitos são erosivos ou bruscos e os de topo, bruscos ou gradativos. Algumas vezes, os topos dos metaconglomerados são marcados por superfícies onduladas de natureza erosiva. Esses metaconglomerados são de cor cinza-amarelada a avermelhada, mal selecionados, com fragmentos da fração cascalhosa sāo constituídos arenosa contendo proporçōes variáveis de grânulos. Os fragmentos da fração cascalhosa são constituídos predominantemente de quartzito de cores rosa, cinza, creme e vermelha, de rocha vulcânica, de metarenitos e, mais raramente, de quartzo leitoso. Nos níveis mais basais, as proporções de fragmentos de quartzito e de rocha vulcânica são aproximadamente equivalentes enquanto, nos níveis superiores, existe uma predominancia de fragmentos de quartzito que, em alguns casos, pode atingir $2 / 3$ da fração cascalho. Os fragmentos são dominantemente arrendondados; dentre os angulares, predominam aqueles constituídos de quartzito. A esfericidade é em geral de média a baixa, com predomínio da forma discoidal, seguida de lamelar e, em menor porcentagem, da esférica. Os fragmentos cascalhosos se apresentam quase sempre orientados subparalelamente à foliação da rocha, constituindo uma trama com características semelhantes às consideradas por Pettijohn (1975) como tipicamente de deformação. A matriz é constituída predominantemente de quartzo e de proporções variáveis de fragmentos de rocha vulcânica, de quartzitos è de metarenitos. A relação cascalho/matriz é bastante variável e os metaconglomerados podem exibir um arranjo interno que vai de níveis com alta razão cascalho/matriz, em que as partículas cascalhosas se apóiam uma nas outras, a horizontes com baixa razão cascalho/matriz, em que os fragmentos estão dispersos no seio da matriz arenosa.

DISCUSSÃO Areias com laminação plano-paralela apresentando características semelhantes às exibidas pelos quartzitos e metarenitos da fácies 1 representam um tipo faciologico comumente encontrado em praias ou em outras áreas sujeitas à ação de ondas. Nas regiōes de praia, essas laminaçöes, cuja origem é atribuída à ação de fluxo e refluxo das ondas (Reineck 1963), geralmente mostram gradação textural ou mineralógica (Sanders 1965, Clifton 1969). As lâminas têm espessura de 1 a $2 \mathrm{~mm}$, são uniformes e regulares, e apresentam uma grande extensão lateral. Nas regiôes de inframare, essas lâminas podem também ser produzidas pela deposição de areia pela ação de correntes que fluem em lençol (sheet flow), geradas pela passagem de ondas, especialmente em costas abertas com ondas de alta energia (Clifton et al. 1971). Ainda nessas regiōes, um importante processo de gênese de areias laminadas é a sedimentação de nuvens de suspensão, quando a velocidade da corrente se torna muito baixa. As marcas onduladas simétricas presentes nos topos dos bancos são indicativas da ação de ondas. Outras feições que ocorrem associadas com os horizontes laminados da fácies $1 \mathrm{e}$, segundo Raaf et al. (1977), têm também a sua gênese 

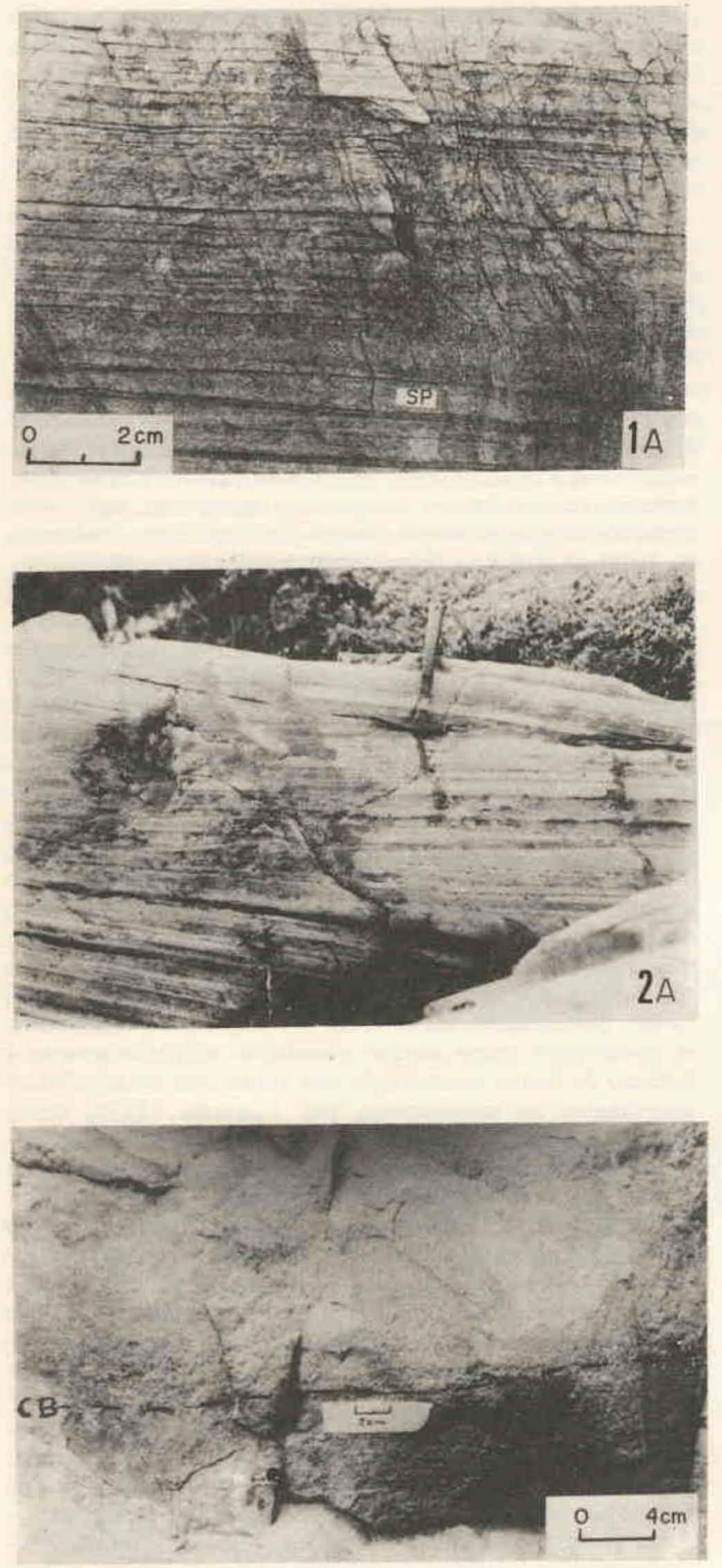

relacionada com a ação de ondas, são: 1. ocorrências de níveis de laminaçōes onduladas paralelas. Essas laminaçōes formam muitas vezes estruturas do tipo pinch-and-swell e comumente se apresentam limitadas no topo por superfícies de erosão (Foto 1A); 2. presença de superfícies de truncamento onduladas; e 3. laminações cruzadas truncadas no topo por superfícies onduladas de natureza erosiva.

As laminaçōes cruzadas de baixo ângulo que se associam intimamente com as laminaçöes plano-paralelas são características de praias e bancos costeiros (McKee 1957, McKee \& Sterrett 1961). Elas resultam da sedimentação, por ação de ondas, de lâminas arenosas nas superfícies com baixo declive das praias e das faces dos bancos voltados para o mar.

As estratificaçōes cruzadas tabulares que aparecem em seqüências isoladas podem ser classificadas como do tipo Alpha
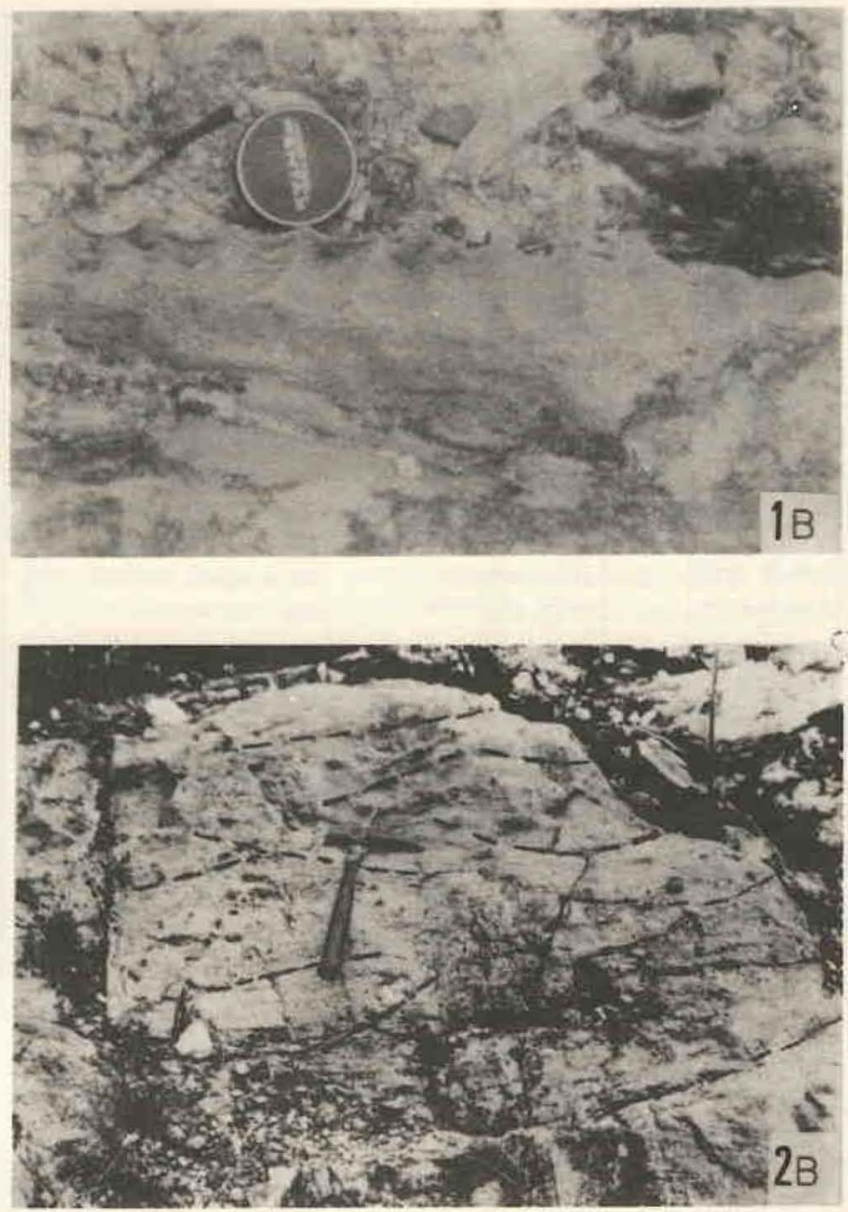

Foto 1 - Fácies de quartzitos e metarenitos laminados (fácies 1): A. quartzitos com laminação plana mostrando contatos bruscos entre as lâminas representados por superficies erosivas planas ou suavemente onduladas. Notar estrutura do tipo pinch-and-swell (SP), afloramento a sul de Rio de Contas; B. marcas onduladas simétricas no topo dos bancos de quartzitos, afloramento na estrada para Joâo Dias

Foto 2 - Fácies de quartzitos e metarenitos laminados (fácies 1): A. estratificaçōes cruzadas cuneiformes mostrando direções variáveis e baixos ângulos de mergulho, afloramento no leito do Rio Brumado, próximo a Rio de Contas; B. estratificações cruzadas acanaladas, afloramento na estrada para João Dias

Foto 3 - Fácies de quartzitos e metarenitos laminados (fácies 1). Estratificação gradativa normal exibindo contato basal brusco (CB), afloramento no leito do Rio Brumado, próximo à Cachoeira do Fraga

de Allen (1963), que geralmente se desenvolvem em águas pouco profundas como resultado da migração de bancos solitários sob a ação de correntes com velocidades moderadas. Essas estruturas são, deste modo, consideradas como correspondentes às seqüências cruzadas de alto ângulo desenvolvidas na face voltada para o continente dos bancos costeiros (Thompson 1937, McKee \& Sterrett op. cit., Hoyt 1962, Bigarella 1965). As estratificaçōes que formam seqüências de geometria cuneiforme com camadas frontais apresentando direçōes variáveis e ângulos de mergulho baixos são comparáveis às estruturas do tipo $X i$ de Allen (op. cit.), encontradas em regiões de pós-praia (McKee op. cit.) e de estirâncio (Thompson op. cit.). Elas correspondem às estratificaçōes desenvolvidas nas faixas da praia sujeitas à ação de fluxo e refluxo (estratificação do tipo swash de Harms 
1975), cujas características distintivas são: 1. os baixos ângulos de mergulho das seqüências cruzadas e das superfícies de contato entre as mesmas; 2 . as superfícies de contato são geralmente de natureza erosiva e apenas raramente não erosiva; e 3. lâminas cruzadas dispostas paralelamente às superfícies de contato entre as seqüências ou ligeiramente divergentes. Essas características refletem as mudanças constantes de profundidade, velocidade e direção do fluxo, típicas das zonas sujeitas à ação de fluxo e refluxo das ondas.

As estratificaçōes cruzadas acanaladas organizadas em co-seqüências são consideradas como equivalentes às seqüências cruzadas encontradas atualmente em regiőes de antepraia e que se desenvolvem a partir da migração de formas de leito onduladas com cristas sinuosas ou com geometria luniforme (Clifton et al. op. cit., Harms op. cit.).

As estratificaçōes gradativas apresentam características que, segundo Reineck \& Singh (1980), são indicativas de deposiçẩo em águas rasas representadas por unidades com espessuras centimétricas, formando níveis isolados e esporádicos. Essas estruturas são, dessa forma, interpretadas como formadas em uma região de antepraia pela deposição de sedimentos erodidos das zonas de pós-praia e de estirâncio durante períodos de tempestades e carreados por correntes de turbidez geradas durante esses mesmos períodos.

Os metaconglomerados são constıcuídos, em boa parte, de fragmentos cascalhosos de grande tamanho, o que evidencia o pouco transporte sofrido pelos mesmos e, conseqüentemente, uma grande proximidade da área-fonte. Eles sâo, dessa forma, interpretados como resultantes da consolidação de sedimentos cascalhosos originalmente depositados em uma região de praia pela ação erosiva das ondas sobre as áreas marginais adjacentes. A interpretação da deposição desses conglomerados em um ambiente praial foi feita tomando por base os seguintes aspectos: 1. os metaconglomerados estão na maioria das vezes intimamente associados aos metarenitos e quartzitos laminados e, em alguns casos, em contato gradativo; 2. os topos dos metaconglomerados são marcados algumas vezes por superfícies de erosão onduladas sugestivas de ação de ondas; e 3. os metaconglomerados apresentam, muitas vezes, uma alta segregação de fragmentos cascalhosos, com estratos de pouca espessura, o que suporta a interpretação de deposição em ambiente praial (Clifton 1973).

Fácies 2 - Quartzitos com estratificações cruzadas de grande porte As rochas que integram esta fácies se distribuem na porção mais central da área, em cotas variáveis entre 1.000 e $1.200 \mathrm{~m}$, estando em parte recobertas por sedimentos terrígenos inconsolidados que constituem as coberturas cenozóicas (Fig. 2). Afloram em ambos os flancos do sinclinório de Rio de Contas, constituindo duas faixas com largura variável de 600 a $1.400 \mathrm{~m}$ alongadas na direção NW-SE. Excelentes exposições desta fácies são encontradas a norte da cidade de Rio de Contas, na trilha que leva à Fazenda Joâo Dias, e ao longo das estradas que ligam Rio de Contas a Marcolino Moura e a Livramento de Nossa Senhora. Estratigraficamente, esta fácies está sobreposta aos metassedimentos da fácies 1 .

Os quartzitos da fácies 2 têm uma espessura estimada de cerca de $200 \mathrm{~m}$, são de cor cinza a branca e granulação média a fina. São constituídos quase que exclusivamente de grãos de quartzo de granulação média a fina, com as dimensões maiores fortemente orientadas. O selecionamento é muito bom e nos grãos cujos contornos originais sâo ainda preservados observa-se um alto grau de arredondamento. Os interstícios entre os gräos são ocupados por um mosaico de quartzo de granulação mais fina. É também comum a presença de sericita de origem diagenética ou metamórfica formando filmes orientados paralelamente ao contorno dos grãos.

A característica mais notável da fácies 2 é a ocorrência generalizada, ao longo de toda a seção da mesma, de estratificaçőes cruzadas de grande porte com a morfologia tabular, em cunha ou acanalada, e cujas camadas frontais exibem mergulhos de até $35^{\circ}$ e, excepcionalmente, $40^{\circ}$. Mais raramente, horizontes com laminação plana bastante regular e uniforme, com espessuras variando de 0,50 a $1,20 \mathrm{~m}$, podem ser encontrados associados aos estratos cruzados.

As estratificaçōes cruzadas com morfologia tabular e em cunha (Fotos 4A e 4B) têm ocorrências mais freqüentes nas partes basais da fácies. Formam unidades com espessuras que atingem muitas vezes $5 \mathrm{~m}$ e, excepcionalmente, $15-20 \mathrm{~m}$. Próximo ao topo de cada unidade cruzada as camadas frontais podem apresentar ângulo de mergulho muito forte, que diminui gradativamente para a base onde essas camadas frontais tendem a se tornar paralelas à superfície basal. As estratificaçőes cruzadas acanaladas aparecem de preferência nas partes intermediárias e de topo da seção. Formam em geral unidades com espessuras de 1 a $2 \mathrm{~m}$ que se associam em co-seqüências cujas espessuras podem atingir valores superiores a $10-15 \mathrm{~m}$ (Foto 5).

DISCUSSÃO Os quartzitos da fácies 2 são interpretados como de origem eólica acumulados sob a forma de dunas, tomando por base principalmente a grande espessura das unidades cruzadas presentes nos mesmos e os fortes ângulos de mergulho de suas camadas frontais. Essas características das estratificaçōes cruzadas constituem um dos critérios mais importantes para o reconhecimento de depósitos eólicos antigos (Bigarella 1972, Selley 1980, Ahlbrandt \& Fryberger 1982). A ubiqüidade da ocorrência das estratificaçōes através da fácies é um outro aspecto importante como indicativo da origem é́lica da mesma (Walker \& Middleton 1979). Reforçam ainda essa interpretação a constituição mineralógica essencialmente quartzosa, a granulação média a fina, o bom selecionamento e o alto grau de arredondamento das partículas que constituem os quartzitos. Essa conjugação de feiçōes configura um dos elementos mais significativos de diagnose para a caracterização de sedimentos eólicos (Reading 1978).

Os níveis com laminação plana que ocorrem esporadicamente ao longo da fácies são um tipo de estrutura freqüentemente encontrado em sedimentos de origem eólica (Bagnold 1954, Glennie 1970, Reineck \& Singh 1980, McKee \& Tibbits 1964, Sharp 1966, Inman et al. 1966). Essas laminaçōes são comumente desenvolvidas nas partes de barlavento, flancos e próximo às partes mais altas das dunas eólicas, ou ainda em regiōes interdunares (Hunter 1977, Reineck \& Singh op cit.).

Fácies 3 - Metarenitos finos laminados, metassiltitos e ardósias Os metassedimentos desta fácies constituem o topo da sequiência do Grupo Paraguaçu na área estudada. Afloram na zona do núcleo e do flanco NE do sinclinório de Rio de Contas, encontrando-se em grande parte recobertos pelos sedimentos terciários-quaternários (Fig. 2). Suas melhores exposições são encontradas a leste da cidade de Rio de Contas, onde eles apresentam uma largura máxima de afloramento em torno de $1.000 \mathrm{~m}$. Os metassedimentos da fácies 3 se sobrepõem aos quartzitos da fácies 2 e sua espessura mínima é de cerca de $270 \mathrm{~m}$. Foram distinguidas três subfácies compondo os metassedimentos da fácies 3: 1. sub-fácies $3 \mathrm{~A}$ - metarenitos finos laminados; 2. subfácies $3 \mathrm{~B}$ - metassiltitos e ardósias intercalados e 3. subfácies 3C metassiltitos com laminação lenticular.

\section{SUBFÁCIES $3 A$ - METARENITOS FINOS}

LAMINADOS Esta subfácies constitui a parte basal da seqüência representativa da fácies 3 , sendo formada por um pacote de metarenitos de cor cinza-esbranquiçada a creme, com granulação fina, apresentando intercalações centimétricas de metassiltitos e ardósias. Esses metarenitos são constituídos 
essencialmente de quartzo, que na maioria das vezes atinge porcentagens acima de $95 \%$. Estão também presentes sericita em quantidades subordinadas e muito raramente turmalina e zircăo. $\mathrm{O}$ quartzo ocorre em grãos xenoblásticos, ineqüigranulares, com tamanhos na faixa de 0,1 a $0,4 \mathrm{~mm}$, com contatos reentrantes e, menos freqüentemente, do tipo longo. A sericita se apresenta sob a forma de finas palhetas orientadas ocupando os interstícios entre os grãos de quartzo. A turmalina se apresenta em grãos xenoblásticos de cor esverdeada. Para o topo da seção a quantidade de sericita aumenta gradativamente podendo atingir valores de ate $15 \%$. A zirconita aparece em grãos xenoblásticos e em forma de bastonetes.

A estrutura sedimentar que caracteriza a subfácies $3 \mathrm{~A}$ é uma laminação plana de espessura milimétrica e grande uniformidade. São também algumas vezes encontradas intercaladas nos níveis laminados, unidades isoladas de estratificação cruzada tabular com espessuras de 0,50 a 1,20 $\mathrm{m}$ e mergulho das lâminas frontais variando de $10^{\circ}$ a $20^{\circ}$. Para o topo da subfácies, as intercalações de metassiltitos e ardósias se tornam mais freqüentes e mais espessas, e os metarenitos passam gradualmente para os metassedimentos da subfácies $3 \mathrm{~B}$.

\section{SUBFÁCIES $3 B$ - METASSILTITOS E ARDÓSIAS INTERCALADOS Esta subfácies constitui a parte} intermediária dos metassedimentos da fácies 3 e é composta por uma sequuência de metassiltitos e ardósias de cores cinza a amarelada, formando níveis intercalados cujas espessuras variam de alguns centímetros a dezenas de metros. Os níveis de metassiltitos são constituf́dos essencialmente de quartzo e sericita e se apresentam com estrutura laminada on maciça, enquanto os níveis ardosianos são essencialmente sericíticos e dominados pela clivagem metamórfica, não tendo sido observada a presença de estruturas sedimentares primárias. $\mathrm{Na}$ parte intermediária da subfácies aparecem frequientemente faixas com espessuras métricas de ritmitos com laminaçâo gradativa. Cada lâmina individual tem espessura submilimétrica a centimétrica e é constituída de areia fina laminada ou esporadicamente com microlaminaçáo cruzada na base, que grada para silte e/ou argila laminados no topo (Foto 6). Essa subfácies é sobreposta por contato gradativo pelos metassedimentos da subfácies $3 \mathrm{C}$.

SUBFÁCIES 3C - METASSILTITOS COM ACAMAMENTO LENTICULAR Esta subfácies constitui o topo dos metassedimentos do Grupo Paraguaçu na área estudada. E representada por metassiltitos amarelados, constituídos essencialmente de quartzo e sericita, apresentando intercalaçōes de lentes quartzosas isoladas com granulometria de areia fina a muito fina, formando um acamamento do tipo lenticular. Internamente, essas lentes exibem uma laminação ondulada paralela (Foto 7A) ou se apresentam com microlaminaçőes cruzadas (Foto 7B). Morfologicamente, as lentes arenosas são espessas (razão comprimento/espessura $>$ 20), segundo a classificação de Reineck \& Singh (op. cit.). E comum também a presença de pequenos diques de areia ramificados a partir das lentes arenosas.

DISCUSSÃO A subfácies de metarenitos finos e laminados (subfácies $3 \mathrm{~A}$ ) é considerada como equivalente às areias laminadas atualmente depositadas em regiões de antepraias (Reineck \& Singh op. cit.) adjacentes a uma plataforma lamosa. Além da laminação característica, a associação em contato gradativo dessa subfácies com os metassedimentos da subfácies $3 \mathrm{~B}$, que, como será visto, mostram evidências de deposição em um ambiente de plataforma, corrobora essa interpretação. As estratificaçōes cruzadas tabulares que aparecem em unidades isoladas intercaladas com o níveis laminados resultism da migração de bancos arenosos comumente encontrados nessas regiőes.

Os metassiltitos e as ardósias intercaladas da subfácies $3 \mathrm{~B}$ são considerados como correspondentes às intercalaçōes siltosas e argilosas encontradas em regiōes de plataforma atuais. Essa interpretação é baseada na natureza essencialmente lamosa da subfácies e na presença dos níveis de ritmitos com laminaçạ̃o gradativa. As alternâncias te niveis siltosos e argilosos são típicas de regiōes de platatorma e refletem variaçöes nas condições hidrodinâmicas ambientais durante a sedimentação. Assim, a depoșição do material argiloso se processa nos períodos normais de águas calmas enquanto os níveis siltosos são representativos de uma deposiçăo em condições de maior agitação das águas, correspondentes a períodos de tempestades (Hayes 1967, Reineck et al. 1967, Gadow \& Reineck 1969). Os ritmitos com laminação gradativa são caracteristicamente formados $\mathrm{sm}$ ambientes de plataforma e também geneticanente relacionados a períodos de tempestade. Eles resultam da deposição a partir de nuvens de suspensão e de correntes de turbidez geradas durante esses períodos (Gadow e Reineck $o p$, cit., Reineck \& Singh op. cit.). A sedimentação desse tipo de depósito se processa normalmente em uma faixa da plataforma relativamente profunda, abaixo do nível de base das ondas de tempestade (Walker 1979).

$\mathrm{Na}$ subfácies 3C, o acamamento lenticular que predomina nos metassedimentos que a constituem é característico de ambientes em que a deposição e a preservação tanto de areias como de sedimentos lamosos é possível, mas onde a deposição desses últimos $\varepsilon$ predominante. Esse tipo de acamamento $\varepsilon$ produzido quando o suprimento de areia é relativamente pequeno e essa se acumula sob a forma de microndulaçöes incompletas em um substrato argiloso, que são recobertas e preservadas pela deposição de novas camadas lamosas. A origem dessas estruturas requer, dessa maneira, uma alternância de períodos em que a atividade de correntes ou de ondas possibilita a deposição de areia, com períodos de maior calma, quando são então depositados os sedimentos lamosos (Reineck 1969). Assim, as lentes arenosas exibem microlaminaçóes cruzadas que podem resultar tanto da atividade de correntes como da açăo de ondas. $\mathrm{O}$ acamamento lenticular $t$ encontrado principalmente em regiōes de inframaré e de intermaré (Reineck \& Singh op. cit.), onde sua gênese está relacionada com a alternância de períodos de atividade de correntes e de calma, que marca o ritmo das marés. Menos comumente, o acamamento lenticular é encontrado em depósitos de deltas marinhos (Coleman \& Gagliano 1965), em pequenos deltas lacustres (Coleman 1966) e em zonas de transição para a plataforma (Reineck \& Singh $o p$. cit.). A grande dominância do acamamento lenticular nos metassedimentos da subfáceis $3 \mathrm{C}$ favorece a interpretação de uma deposição em um ambiente de maré, visto que essa dominância e a formação de co-seqüências, como se observa nesses metassedimentos, são características desses ambientes (Reineck \& Singh op. cit.). A predominância de lama sobre a areia e o contato gradativo com os metassedimentos de origem plataformal da subfácies $3 \mathrm{~B}$ sugerem uma deposição na faixa inferior de uma região de inframaré.

MODELO DE SEDIMENTAÇÃo DO GRUPO PARAGUAÇU A formulação de um modelo de sedimentação para os metassedimentos do Grupo Paraguaçu na área estudada deve necessariamente levar em conta as características distintas das fácies componentes do mesmo, o que implica grandes mudanças nas condiçōes de sedimentação e, portanto, grandes variaçōes ambientais. A natureza das relaçőes entre as fácies e a constituiçăo essencialmente terrígena de toda seqüência são também elementos fundamentais a serem considerados.

Os metarenitos e quartzitos laminados da fácies 1, constituintes da parte basal do grupo, são interpretados a 

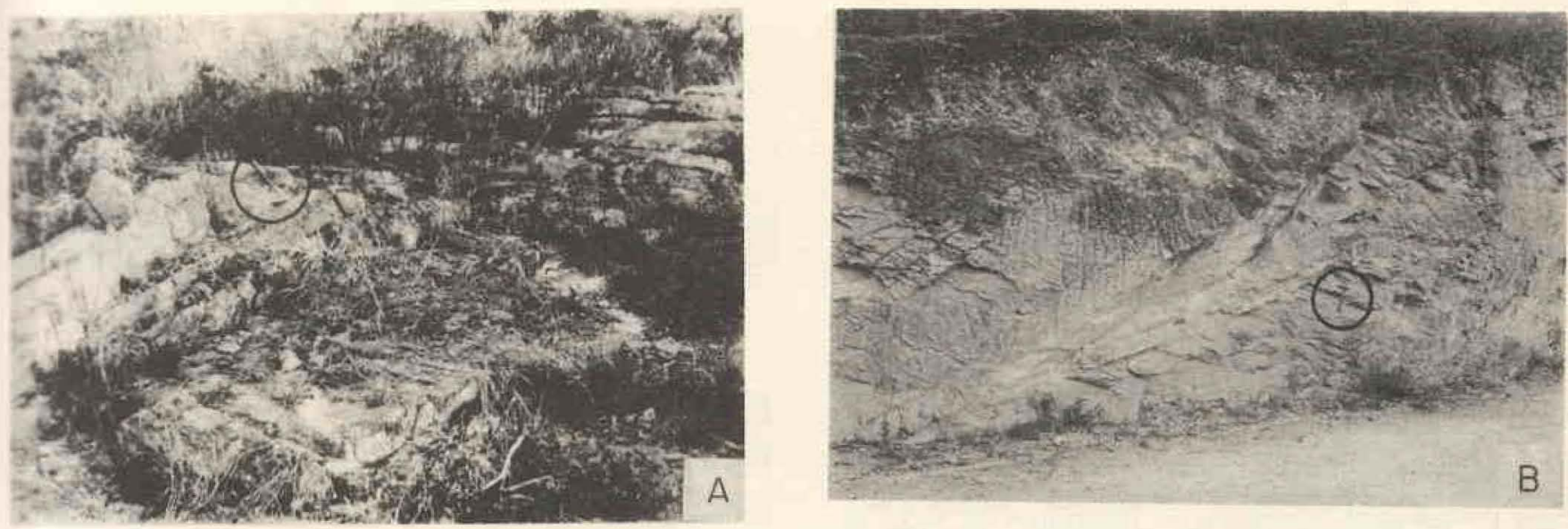

Foto 4 - Fácies de quartzitos com estratificações cruzadas de grande porte (fácies 2): A. estratificação cruzada tabular, afloramento $m$ estrada para João Dias; B. estratificaçōes cruzadas com morfologia em cunha, afloramento na estrada Rio de Contas-Marcolino Moura. Os círculos que aparecem nas fotos destacam os martelos

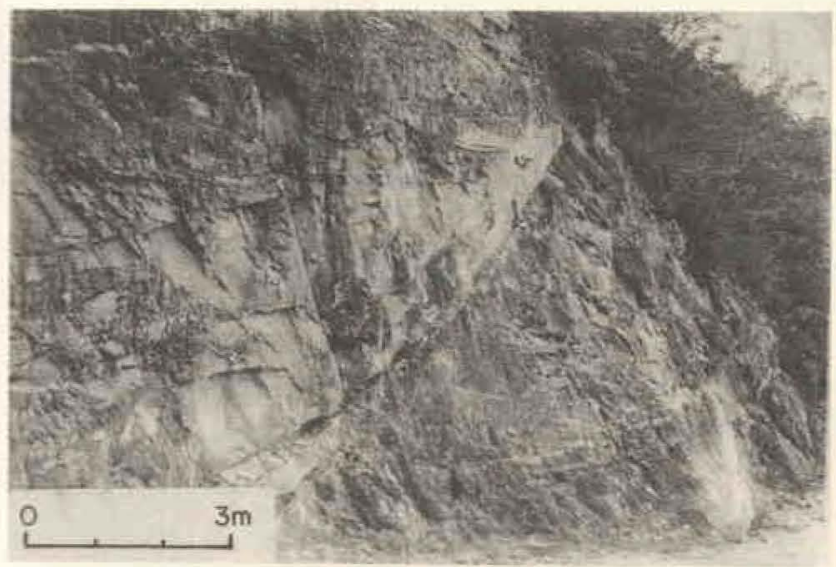

Foto 5 - Fácies de quartizitos com estratificações cruzadas de grande porte (fácies 2): estratificações cruzadas acanaladas, afloramento na estrada Rio de Contas-Marcolino Moura

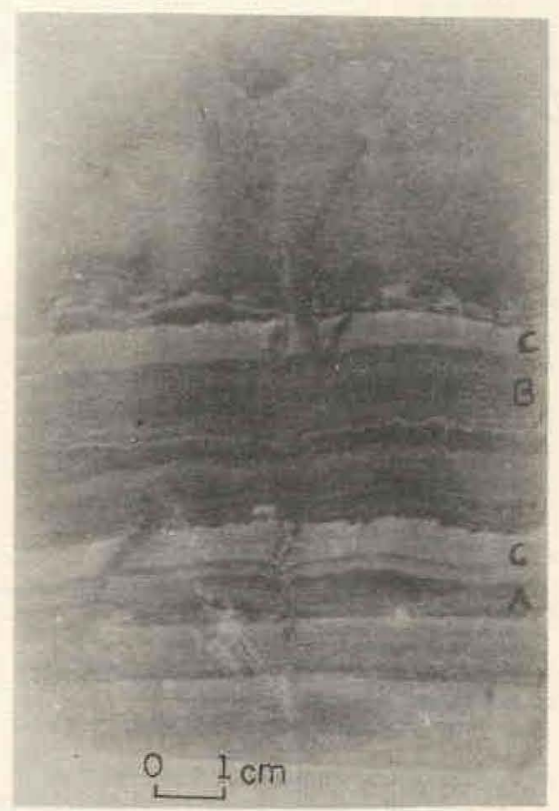

Foto 6 - Subfácies de metassiltitos e ardósias intercaladas (subfácies 3B). Amostra dos ritmitos com laminaçâo gradativa. Notar niveis arenosos com laminação plana $(B)$ ou microcruzada (A) na base, que gradam para siltelargila laminada (C), no topo; afloramento a nordeste de Rio de Contas

Foto 7 - Amostras da subfácies de metassiltitos com acamadamento lenticular (subfácies 3C): A. notar as lentes isoladas de metarenitos (A) com laminaçōes onduladas (mais escuros) intercaladas nos metassiltitos com laminaçôes planas e onduladas (mais claros); B. observar as lentes de metarenitos com laminaçâo ondulada (A) e microlaminação cruzada (B) intercaladas nos metassiltitos com laminaçōes planas e onduladas (C), afloramentos a nordeste de Rio de Contas 
partir de um modelo de sedimentação que está calcado nos seguintes aspectos: 1. eles formam um pacote relativamente espesso de sedimentos essencialmente arenosos e desprovidos de lama e 2. as estruturas sedimentares presentes caracterizam deposição em ambiente litorâneo com o desenvolvimento de praias e bancos costeiros.

A figura 4 mostra um esquema representativo dos ambientes de deposição da fácies 1 relacionados com um período transgressivo e o desenvolvimento de uma extensa plataforma marinha rasa. A grande espessura dos sedimentos e o desenvolvimento de praias e bancos costeiros implica afluxo constante de sedimentos trazidos diretamente por rios ou pela deriva litorânea. A persistência de um ambiente litorâneo durante toda a sedimentação reflete um esquilíbrio entre as taxas de subsidência e de sedimentação. No início da deposição, a presença de areias imaturas contendo algumas vezes porcentagens apreciáveis de fragmentos de rocha de origem vulcânica indica provavelmente maior proximidade da área-fonte constituída em grande parte por este tipo de rocha. A granulometria predominantemente arenosa e desprovida de lama caracteriza região de costa aberta com ondas de moderada a alta energia. Correntes de turbidez e/ou nuvens de suspensão geradas durante períodos de tempestade são responsáveis pela deposição de leitos com estratificação gradativa.

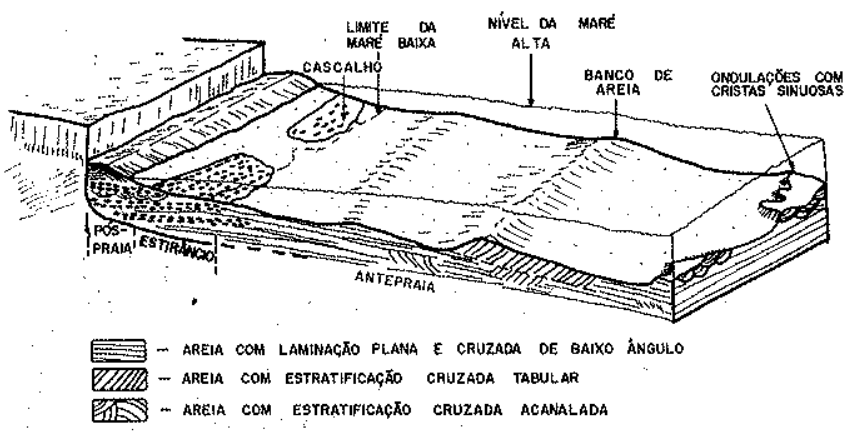

Figura 4 - Esquema representativo dos ambientes de deposição da fácies 1

O fim da deposição dos sedimentos da fácies 1 é marcado por um grande período de emersão e exposição de extensas planícies arenosas correspondentes às regiōes anteriormente submersas. O retrabalhamento pelo vento dos sedimentos arenosos expostos promoveu a formação de vastos campos de dunas que deram origem aos metassedimentos da fácies 2 . Embora a grande espessura de sedimentos eólicos possa ser evocativa de deposição em ambiente desértico, a ausência de depósitos evaporíticos, tipos particulares de solos e outras feiçōes freqüentemente associadas a antigos depósitos de deserto (Glennie 1970, Reading 1978) nāo dão suporte a tal interpretação. Por outro lado, a posição estratigráfica da fácies 2 , intercalada entre os depósitos litorâneos das fácies 1 e 3 (subfácies 3A), é uma forte evidência da formação das dunas em ambiente costeiro. A figura 5 apresenta um modelo esquemático da fácies 2 .

O começo da sedimentação da fácies 3 corresponde ao início de um ciclo transgressivo e da deposição dos sedimentos da subfácies $3 \mathrm{~A}$ em uma região de antepraia, em que condiçōes de energia moderada favorecem a acumulação de areia e eventualmente de sedimentos lamosos. Com a evoluçăo do ciclo transgressivo, esses sedimentos passam gradativamente para os depósitos de plataforma da subfácies $3 \mathrm{~B}$, com a sedimentação agora grandemente controlada por variaçōes nas conđiçōes hidrodinâtmicas ambientais resultando na deposição de argila em períodos normais de calma e de silte

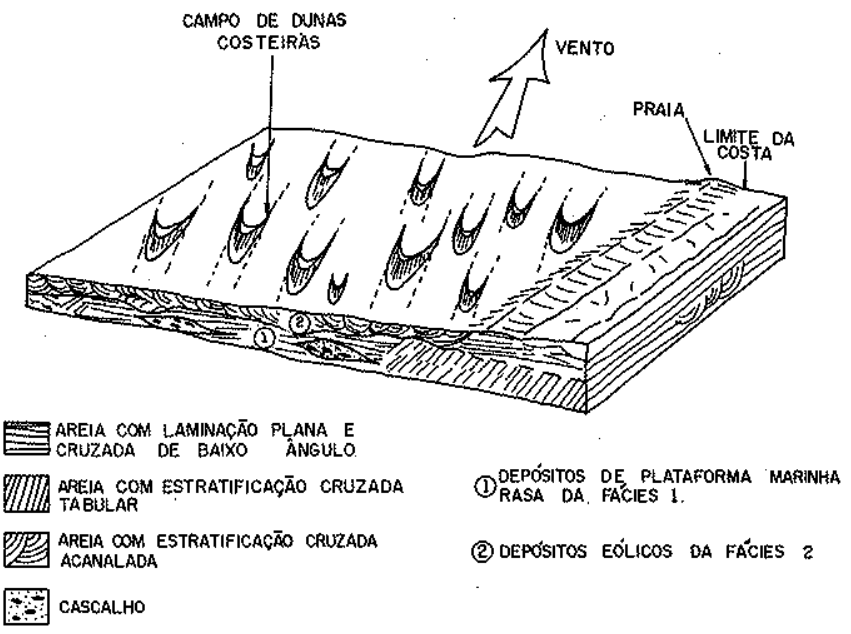

Figura 5 - Esquema representativo do ambiente de deposição da fácies 2 . A posição da linha da costa $e$ a direção do vento são esquemáticas, não tendo sido determinadas

em períodos de maior turbulência, relacionados com tempestades. Correntes de turbidez geradas em períodos de tempestades mais intensas são responsáveis pela sedimentação de depósitos de ritmitos com laminação gradativa. $O$ fím do ciclo transgressivo marca o início da deposição da subfácies 3C representada por sedimentos da faixa de antepraia, que progradam sobre a regiäo da plataforma. As figuras 6 e 7 mostram esquematicamente o modelo de evolução ambiental na deposição dos sedimentos da fácies 3 .

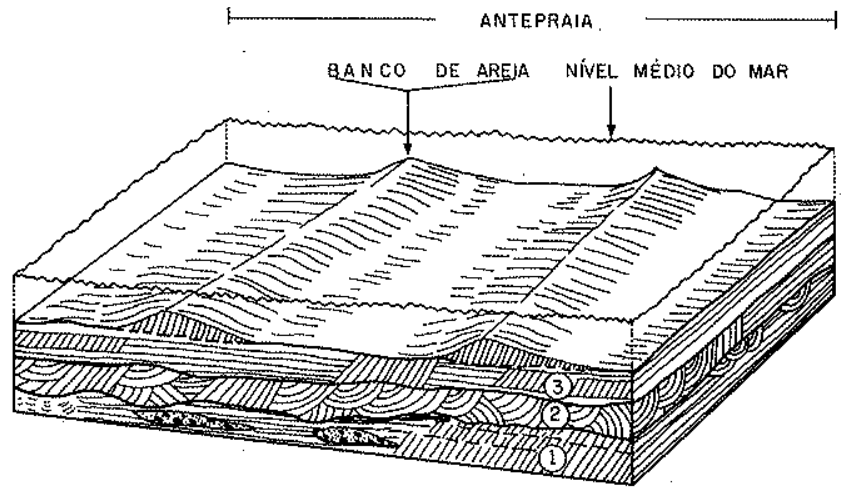

AREIA COM LAMINACÄO PLANA E
CRUZADA OE BAIXO ANGULO
AIIIIIIA CREIA COM ESTRATIGLACACAOA
CRABULAR
CRUZIA COM ESTRATIFICACĀO
CASCALHO

(1) DEPOSITOS DE PLATAFORMA MARINHA RASA DA FÁCIES I

(2) DEPÓSITOS EÓLICOS DA (3) DEPOSITOS TRANSGRESSINOS DE

Figura 6 - Esquema representativo do ambiente de deposição da subfácies $3 A$

CONCLUSÕES

O Grupo Paraguaçu na área estudada é constituído por um conjunto de três fácies sedimentares distintas, da base para o topo: 1. fácies 1 - quartzitos $\mathrm{e}$ metarenitos laminados; 2 . fácies 2 - quartzitos com estratificações cruzadas de grande porte; e 3. fácies 3 metarenitos finos laminados, metassiltitos e ardósias. 


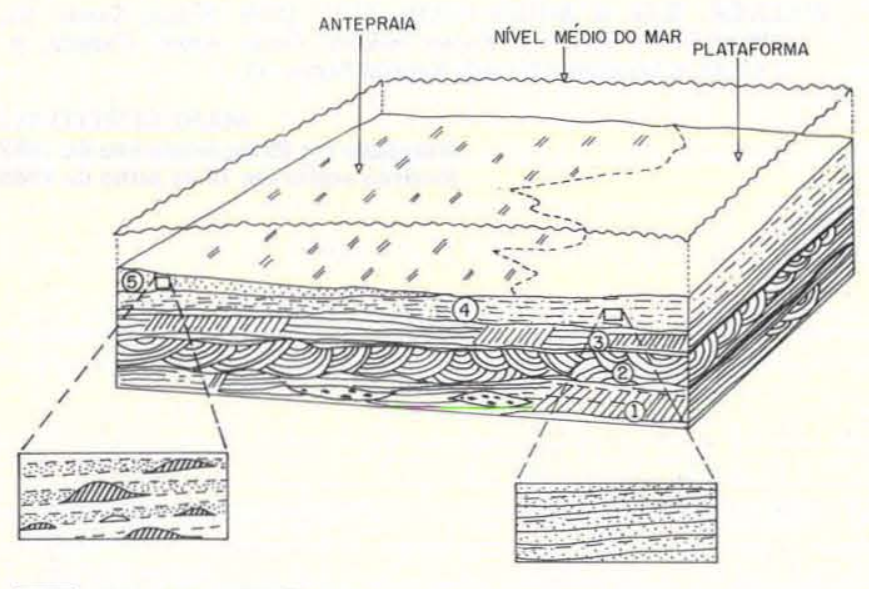

AREIA COM LAMINAC̄ÃO PLANA
AREMA COM ESTRATIFICAÇ̃̃o CRUZADA ACANALADA

LAMA

INTERCALAÇŌES DE SILTE E ARGILA

ACAMADAMENTO LENTICULAR

CASCALHO
AREIA COM ESTRATIFICAGĀo CRU. (1) DEPOSITTS DE PLATAFORMA MA-
RINHA RASA DA FÁCIES 1

(2) DEPÓSITOS EOLICOS DA FÁCIES 2

(3) DEPOSITOS TRANSGRESSIVOS DE
ANTEPRAIA DA SUBFACIES $3 A$

(4) DEPOSITOS TRANSGRESSIYOS DE PLATAFORMA DA SUBFÁCIES 3B (5) DEPÓSITOS PROGRADANTES DE
ANTEPRAIA DA SUBFÁCIES $3 \mathrm{C}$
Figura 7 - Esquema representativo dos ambientes de deposição das subfácies $3 B$ e $3 C$
A fácies 1 é transgressiva e constituída de depósitos litorâneos arenosos, sedimentados em uma extensa plataforma marinha rasa, sujeita à ação de tempestades eventuais.

A fácies 2 consiste em sedimentos arenosos eólicos acumulados em vastos campos de dunas costeiras desenvolvídos sobre extensas planícies arenosas resultantes da emersão de áreas litorâneas anteriormente submersas.

A fácies 3 é composta de três diferentes subfácies, da base para o topo: a. subfácies $3 \mathrm{~A}$ - metarenitos finos laminados constituída de sedimentos litorâneos arenosos, depositados em uma regiâo de antepraia, sob condiçōes de energia moderada; b. subfácies $3 \mathrm{~B}$ - metassiltitos e ardósias intercalados composta por sedimentos lamosos acumulados em uma região de plataforma sujeita a regimes hidrodinâmicos variáveis, alternando períodos normais de calma e períodos de tempestades; c. subfácies $3 \mathrm{C}$-consiste em sedimentos siltosos e arenosos depositados em um ambiente de antepraia progradante sobre uma plataforma lamosa.

Agradecimentos Os autores deixam aqui expressos seus agradecimentos ao Prof. Bráulio M. Baptista, por sua colaboração nos trabalhos de campo. Aos Profs. Abílio C.S.P. Bittencourt e Umberto R. Costa, pelas críticas e sugestões apresentadas. A Gilzélio Reis Nascimento e Elza Azevedo, pelos trabalhos de datilografia. A Natanael P. Gomes e Gilson L. Liberal, pelos trabalhos de desenhos e fotos, respectivamente.

\section{REFERÊNCIAS BIBLIOGRÁFICAS}

AHLBRANDT, T.S. \& FRYBERGER, S.G. 1982. Eolian Deposits. In: SCHOLLE, P.A. \& SPEARING, D. eds. Sandstone depositional environments. Amer. Assoc. Petrol. Geol. p. 11-47. (Memoir 31)

ALLEN, J.R.L. 1963. The classification of cross-stratified units, with notes on their origin. Sedimentology, 2:93-114.

BAGNOLD, R.A. 1954. The physics of blown sand and desert dunes. London, Methuen. 265 p.

BARRETO, L.A.; BRUNI, D.C.; EULÁLIO, H.N.; NEVES, J.P.; TOLEDO, L.A.A.; MOURĀO, L.M.F.; SILVA, L.C.; AZEVEDO, R.R.; MELO, R.C.; MALOUF, R.F. 1975. Projeto Rochas Efusivas, relatório final. Salvador, SME/CPRM. Vol. 1.

BIGARELLA, J.J. 1965. Sand-ridge structures from Paraná Coastal Plain. Marine Geol., 3:269-278.

BIGARELLA, J.J. 1972. Eolian environments: their characteristics, recognition and importance. In: RIGBY, J.K. \& HAMBLIN, W.K. eds. Recognition of ancient sedimentary environment. Soc. Econ. Paleont. Mineral. p. 12-62. (Spec. Publ, 12)

CLIFTON, H.E. 1969. Beach lamination: Nature and origin. Marine Geol., 7:533-539.

CLIFTON, H.E. 1973. Pebble segregation and bed lenticularity in wave-worked versus alluvial gravel. Sedimentology, 20:173-183.

CLIFTON, H.E.; HUNTER, R.E.; PHILLIPS, R.L. 1971. Depositional structures and processes in the non-barred high energy nearshore. J.Sed. Petrol. 41:651-670.

COLEMAN, J.M. 1966. Ecological changes in a massive fresh-water clay sequence. Trans. Gulf Coast. Assoc. Geol. Soc.. 16:159-174.

COLEMAN, J.M. \& GAGLIANO, S.M. 1965. Sedimentary structures: Mississippi River deltaic plain. In: MIDDLETON, G.V. ed., Primary sedimentary structures and their hydrodynamic interpretation. Soc. Econ. Paleont. Mineral. p. 133-148. (Spec. Publ. 12)

GADOW, S. \& REINECK, H.E. 1969. Ablandiger Sandtransport bel sturnfluten. Senckenbergiana marit., I:63-78.

GLENNIE, K.W. 1970. Desert sedimentary environments. Developments in Sedimentology, 14. Amsterdam, Elsevier, $222 \mathrm{p}$.

HARMS, J.C. 1975. Stratification and sequences in prograding shoreline deposits. Soc. Econ. Paleont. Mineral. p. 81-102. (Short Course

HAYES, M.O. 1967. Hurricance as geological agents, South Texas Coast. Am. Assoc. Petrol. Geol. Bull., 51:937-942.

HOYT, J.H. 1962. High-angle beach stratification, Sapelo Island, Georgia. J.Sed. Petrol., 32:309-311.
HUNTER, R.E. 1977. Basic types of stratification in small eolian dunes. Sedimentology, 24:361-387.

INDA, H.A.V. \& BARBOSA, J.F. 1978. Mapa Geológico do Estado da Bahia Escala (1:1.000.000). Texto explicativo. Salvador, Secret. Minas e Energia-CPM. 137 p.

INMAN, D.L.; EWING, G.C.; CORLISS, J.B. 1966. Coastal sand dunes of Guerrero Negro, Baja California, Mexico. Geol. Soc. Amer. Bull., 77:787-802.

McKEE, E.D. 1957, Primary structures in some recents sediments. Am. Assoc. Petrol. Geol. Bull., 41:1704-1747.

McKEE, E.D. \& STERRETT, T.S. 1961. Laboratory experiments on form and structure of longshore bars and beaches. In: PETERSON, J.A. \& OSMOND, J.C. eds. Geometry of sandstone bodies. Amer. Assoc. Petrol. Geol. p. 13-28.

McKEE E.D. \& TIBBITS Jr., G.C. 1964. Primary structures of a Seif dune and associated deposits in Libya. J. Sed.Pet., 34:5-17.

MOUTINHO DA COSTA, L.A. \& INDA, H.A.V. 1982. O aulacógeno do Espinhaço. Ciências da Terra, (2):13-18.

PETTIJOHN, F.J. 1975. Sedimentary rocks. 3 ed. New York, Harper \& Row. 628 p.

RAAF, J.F.M. da; BOERSMA, R.J.; GELDER, A. Van. 1977. Wave-generated structures and sequences from a shallow marine succession, Lower Carboniferous, County Cork, Ireland. Sedimentology, 24:451-483.

READING, H.G. ed. 1978. Sedimentary environment and facies. Oxford, Blackwell Sci. Publ. 576 p.

REINECK, H.E. 1963. Sedimentgefüge im Bereich der südlichem Nordsee. Abh. Senckenbergische naturforch. Ges., 505:1-138.

REINECK, H.E. 1969. Die Entstehung von Runzelmarken. Seckenbergiana marit., I: 165-168.

REINECK, H.E.; SINGH, I.B. 1980. Depositional sedimentary environments. $2 \mathrm{ed}$. Berlin, Springer-Verlag. $549 \mathrm{p}$.

REINECK, H.E.; GUTMAN, W.F.; HERTWECK, G. 1967. Das Schlickgebiet südlich Helgoland als Beispel Rezenter Schelf-ablagerunden. Senckenbergiana Lethaea, 48:219-275.

SANDERS, J.E. 1965. Primary sedimentary structures formed by turbidity currents and related resedimentation mechanisms. In. MIDDLETON, G.V. Ed. Primary sedimentary structures and their hydrodynamic interpretation. Soc. Econ. Paleont. Mineral. p. 192-219. (Spec. publ. 12)

SELLEY, R.C. 1980. Ancient sedimentary environments. 2 ed. New York, Cornell Univ. Press. 287 p. 
SHARP, R.P. 1966. Kelso Dunes, Mojave Desert, California. Geol. Soc. Amer, Bull., 77:1045-1074.

THOMPSON, W.O. 1937, Original structures of beaches, bars and dunes. Geol. Soc. Amer. Bull., 48:723m752.

WALKER, R.G. 1979. Shallow marine sands. In: WALKER, R.G. ed. Facies models. Geoscience Canada Reprint Series 1. Geol. Assoc. Canada, p. 75-89.
WALKER, R.G. \& MIDDLETON, G.V. 1979. Eolian Sands. In: WALKER, R.G. ed. Facies models. Geol. Assoc. Canada, p. 33-41. (Geoscience Canada Reprint Series. 1)

MANUSCRITO 511

Recebido em 09 de dezembro de 1987 Revisão aceita em 18 de julho de 1988

\section{A RBG FEZ ALGO QUE VOCÊ NÃO USA PARA LER A RBG}

A RBG criou uma lupa-escala para suas fotografias e para seus trabalhos de campo, enviada em julho último a todos os associados quites. Se você não a recebeu, escreva para a SBG.

Esta prática solução, destinada a auxiliá-lo em seus trabalhos, provavelmente nunca será necessária para você ler os artigos que a Revista Brasileira de Geociências publica. Simplesmente porque a diagramaçäo procura respeitar regras de legibilidade do produto impresso.

No entanto, é muito provável que no futuro você encontre essa mesma lupa-escala outras vezes na RBG. Esperamos que seja nas fotografias de campo e laboratório de muitos dos nossos autores.
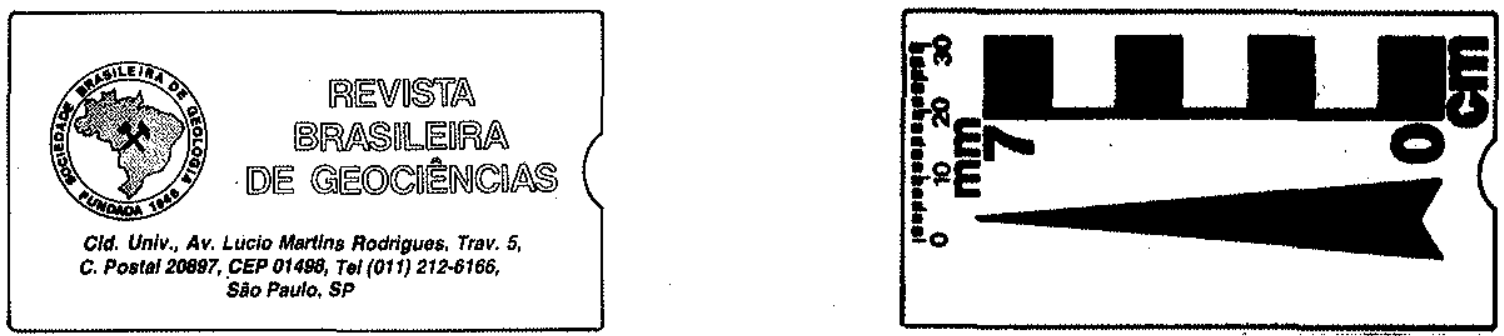

$($ tamanho real $=9 \times 5 \mathrm{~cm})$

corte aqui ou faça cópias

COLE AQUI SUA ETIQUETA DE ENDEREÇAMENTO

OU FORNEÇA EM SEPARADO OS DADOS DA PESSOA A QUEM

A SBG DEVE ENVIAR A(S) LUPA(S)-ESCALA(S)

( ) SIM, desejo receber mais exemplares da lupa-escala da RBG, ao preço unitário de 0,2 OTN (incluindo postagem).

Para tantó, envio cheque nominal à Sociedade Brasileira de Geologia, no valor de Cz\$ banco

Local:

Data:

Assinatura: 